\title{
Net Energy Prediction Equations Used in Chinese Yellow Chickens for Energy Evaluation
}

http://dx.doi.org/10.1590/1806-9061-2020-1293

\section{mAuthor(s)}

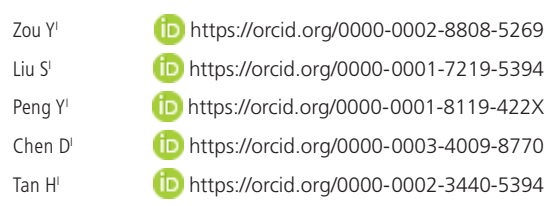

Poultry Business Division of Wens Foodstuff Group Co., LTD., Ministry of Agriculture Key Laboratory of Animal Nutrition and Feed Science, Department of Poultry Nutrition and Feed Science, Xinxing County, Yunfu City, Guangdong Province, China.

\section{-Mail Address}

Corresponding author e-mail address Tan Huize

Xinxing County, Yunfu City, Guangdong

Province, 527400, China.

Phone: 07662929052

Email: tanhuize5@163.com

\section{-Keywords}

Net energy, Chinese Yellow Chickens, prediction equation.

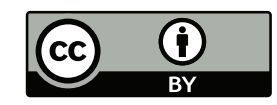

Submitted: 12/December/2020 Approved: 19/March/2021

\section{ABSTRACT}

This study assessed whether the net energy (NE) system is beneficial for determining the efficiency of feed utilization in Chinese Yellow Chickens. A total of 5,600 male Chinese Yellow Chickens were assigned to eight dietary treatments (ten replicate pens per treatment and 70 chickens per pen) of differing apparent metabolizable energy (AME) and $\mathrm{NE}$ values. A highly significant linear correlation between dietary energy and feed conversion ratios (FCR) was observed $(p<0.01)$. The linear regression equation between metabolizable energy (ME) and FCR was: $A M E=-1435.5 \times F / G+6278.2$, where $R^{2}=0.8272$. The linear regression equation between $\mathrm{NE}$ and $\mathrm{FCR}$ was $\mathrm{NE}=-1350.1 \times \mathrm{F} / \mathrm{G}+5340.9$, and $R^{2}=0.9551$. The $R^{2}$ of FCR (0.9551) for diets formulated using NE values was higher than the $R^{2}$ of FCR (0.8272) for diets prepared on the basis of the ME system. We conclude that the NE system is more accurate than the AME system for determining the energy requirements of Chinese Yellow Chickens.

\section{INTRODUCTION}

Broilers ingest nutrients, including carbohydrates, proteins and lipids. Chemical energy is released and converted into usable energy for tissues and cells to maintain their vital functions. Accurate evaluation of the effective energy value of feed ingredients plays a vital role in broiler production. The metabolizable energy (ME) system is widely used in feed formulation for broilers around the world. Although the ME system has been used as the default system in the broiler industry, it has numerous limitations. Some studies found that the ME system overestimated the energy utilization rate of crude protein and crude fibre, and underestimated the utilization rate of fat and starch. Net energy (NE), which refers to the residual energy in the diet, is equivalent to ME minus total heat production (HP) during in-vivo metabolism, and has also been used in animal production. Heat increment $(\mathrm{HI})$ values from different nutrients differ. Thus, the $\mathrm{HI}$ values of protein and carbohydrate were found to be similar, but both were significantly higher than the $\mathrm{HI}$ of fat.

The NE system is attracting increasing attention in both academia and industry. Noblet (1994) used respiration calorimetry to study the NE system in pigs, and established regression equations between NE values of feed ingredients and their chemical components. The National Research Council used these regression equations to calculate the NE values of feed ingredients in their database. In recent years, the NE system has been applied to broilers. In a thorough and detailed study, Wu et al. (2019) established regression equations between the $\mathrm{NE}$ values of broiler feed ingredients and their chemical components. However, no subsequent study has been carried out to compare NE and ME systems in broilers, particularly under practical conditions. This 
study aimed to estimate the NE values of commonly used feed ingredients for the Chinese Yellow Chicken. The correlation between FCR and feed energy gradient was used to evaluate the accuracy of the NE system compared with the ME system for Chinese Yellow Chickens.

\section{MATERIALS AND METHODS}

\section{Animals, diets, and treatments}

This study was conducted at Wens Foodstuffs Group Co., Ltd. (Guangzhou, China) and was approved by the Animal Care and Handling Procedures of the Institute of Animal Science, Chinese Academy of Agricultural Sciences, Beijing, China. A total of 5,600 Chinese Yellow Chickens (body weight $235 \mathrm{~g}$ ) used in this study were selected from the same farm on the basis of their genetic background and health status. The chickens were divided among eight dietary treatments. Each treatment had ten replicate pens and each pen (2.5 $\times 4 \mathrm{~m}$ ) housed 70 chickens. Mash diets were fed in a three-phase feeding program as follows: starter (days 1 to 21 ), grower (days 22 to 42 ), and finisher (days 43 to 58). The eight diets were formulated to provide a similar nutrient profile but with different energy levels (Table 1). All treatment groups were fed with the same diet in

Table 1 - Ingredients and calculated nutrient composition of experimental diets.

\begin{tabular}{|c|c|c|c|c|c|c|c|c|c|c|c|c|c|c|c|c|c|}
\hline \multirow{2}{*}{$\begin{array}{l}\text { Phase Treatment } \\
\text { Ingredients, g/kg }\end{array}$} & \multirow{2}{*}{$\begin{array}{l}\text { Starter } \\
\text { T1-T8 }\end{array}$} & \multicolumn{8}{|c|}{ Grower } & \multicolumn{8}{|c|}{ Finisher } \\
\hline & & $\mathrm{T} 1$ & $\mathrm{~T} 2$ & T3 & $\mathrm{T} 4$ & T5 & T6 & $\mathrm{T} 7$ & T8 & $\mathrm{T} 1$ & $\mathrm{~T} 2$ & T3 & $\mathrm{T} 4$ & T5 & T6 & $\mathrm{T} 7$ & T8 \\
\hline Corn & 634.5 & 260.0 & 654.1 & 675.1 & 270.0 & 260.0 & 680.8 & 702.1 & 509.0 & 204.0 & 637.0 & 567.2 & 216.0 & 339.1 & 583.0 & 444.7 & 317.7 \\
\hline Soybean meal & 240.1 & 60.0 & 98.1 & 124.5 & 60.0 & 60.0 & 132.0 & 144.0 & 60.0 & 60.0 & 101.6 & 96.6 & 52.0 & 60.0 & 104.6 & 88.9 & 60.0 \\
\hline Cottonseed meal & 40.0 & 21.0 & & & & & & & 23.0 & 10.0 & 25.0 & 15.0 & & & 11.0 & 21.0 & \\
\hline Corn gluten meal & 40.0 & 26.2 & 80.0 & 80.0 & 15.9 & 15.9 & 80.0 & 80.0 & 14.7 & 14.7 & 80.0 & 80.0 & 23.2 & 29.3 & 80.0 & 80.0 & 36.5 \\
\hline Wheat & & & & & & & & & & 50.0 & 50.0 & 50.0 & 50.0 & 50.0 & 50.0 & 50.0 & 50.0 \\
\hline Soybean oil & 4.0 & 40.0 & 4.2 & 9.9 & 40.0 & 40.0 & 17.3 & 22.1 & 40.0 & 50.0 & 18.2 & 28.0 & 55.0 & 50.0 & 34.6 & 49.0 & 60.0 \\
\hline ed meal & & 100.0 & 19.5 & & 96.2 & 94.0 & & & 100.0 & 100.0 & & & 100.0 & 100.0 & & & 88.5 \\
\hline Pea & & 100.0 & 100.0 & 66.3 & 48.4 & 100.0 & 45.5 & 7.4 & & 100.0 & 46.4 & 100.0 & 47.7 & 36.7 & 95.6 & 100.0 & 29.0 \\
\hline Barely & & 300.6 & & & 300.1 & 300.0 & & & 83.0 & 285.0 & & 22.0 & 299.7 & 196.0 & & 125.0 & 211.0 \\
\hline Extruded soybean & & 21.0 & & & 100.0 & 91.0 & & & 100.0 & 60.0 & & & 90.0 & 80.0 & & & 80.0 \\
\hline Palm & & 30.0 & & & 30.0 & & & & 30.0 & 30.0 & & & 30.0 & 22.0 & & & 30.0 \\
\hline Lysine & 4.9 & 6.4 & 7.2 & 7.2 & 5.3 & 4.7 & 7.3 & 7.5 & 6.0 & 4.2 & 6.9 & 6.2 & 4.6 & 4.8 & 6.1 & 6.4 & 5.1 \\
\hline & 1.8 & 3.0 & 2.5 & 2.6 & 2.9 & 3.0 & 2.5 & 2.5 & 2.8 & 2.2 & 1.8 & 1.8 & 2.0 & 1.9 & 1.8 & 1.9 & 1.9 \\
\hline Threo & 0.4 & 1.8 & 1.3 & 1.2 & 1.5 & 1. & 1.2 & 1.1 & 1. & 1. & & 1. & & & 1.0 & 1.1 & 1.2 \\
\hline Salt & 3.5 & 3.5 & 3.6 & 3.6 & 3.5 & 3.5 & 3.6 & 3.6 & 3.4 & 2.9 & 3.0 & 3.1 & 2.9 & 2.9 & 3.1 & 3.1 & 2.9 \\
\hline Na-Bicarbonate & & & & & & & & & & 1.5 & 1.5 & 1.5 & 1.5 & 1.5 & 1.5 & 1.5 & 1.5 \\
\hline & & & & & 13.2 & & & & 13.3 & 12.9 & & 14.0 & & & 13.9 & 14.0 & \\
\hline & 12.4 & 8.6 & 10.8 & 11.0 & 8.5 & 8.6 & 11.1 & 11.1 & 8.9 & 6.9 & 9.2 & 9.2 & 6.9 & 7.3 & 9.4 & 9.0 & 7.4 \\
\hline aPre & 4.0 & 4.0 & 4.0 & 4.0 & 4.0 & 4. & 4.0 & 4.0 & 4. & 4. & & 4. & & & 0 & 4.0 & 4.0 \\
\hline Cho & 0.8 & 0.5 & 0.5 & 0.5 & 0.5 & 0.5 & 0.5 & 0.5 & 0.5 & 0.4 & 0.4 & 0.4 & 0.4 & 0.4 & 0.4 & 0.4 & 0.4 \\
\hline Total Batch & 1000 & 1000 & 1000 & 1000 & 1000 & 1000 & 1000 & 1000 & 100 & 1000 & 1000 & 1000 & 100 & 1000 & 1000 & 1000 & 1000 \\
\hline \multicolumn{18}{|c|}{ Calculated nutrient levels, \% } \\
\hline Crude protein & 20.50 & 17.47 & 17.5 & 17.5 & 17.5 & 7.51 & & & 17.5 & 17.49 & 17.51 & 17.49 & 17.49 & 17.5 & 17.49 & 17.5 & 17.5 \\
\hline & & & 2.77 & 3.33 & 8.1 & 7.68 & & 4.56 & & & & 4.91 & & & 5.56 & 6.86 & 9.6 \\
\hline & 2.43 & 4.74 & 2.28 & 2 & 4.57 & 4.2 & 1.93 & 1.8 & 3.88 & 4.66 & 2.02 & 2.2 & 4.49 & 3.95 & 2.08 & 2.54 & 3.97 \\
\hline Calcium, \% & 0.90 & 0.85 & 0.85 & 0.85 & 0.85 & 0.85 & 0.85 & 0.85 & 0.85 & 0.8 & 0.8 & 0.8 & 0.8 & 0.8 & 0.8 & 0.8 & 0.8 \\
\hline Available phosphorus & 0.351 & 0.31 & 0.311 & 0.31 & 0.311 & 0.31 & 0.31 & 0.309 & 0.31 & 0.28 & 0.281 & 0.28 & 0.281 & 0.28 & 0.281 & 0.281 & 0.28 \\
\hline $\mathrm{Na}^{+}$ & & 0.16 & 0.16 & 0.16 & 0.16 & 0.16 & 0.16 & & 0.16 & 0.18 & 0.18 & 0.18 & 0.18 & 0.18 & 0.18 & 0.18 & 0.18 \\
\hline $\mathrm{K}^{+}$ & & 0.57 & 0.44 & 0.47 & 0.67 & 0.65 & 0.48 & 0.51 & 0.65 & 0.62 & 0.47 & 0.44 & 0.65 & 0.63 & 0.44 & 0.45 & 0.62 \\
\hline AME, kcal/kg & 2900 & 2920 & 2955 & 3000 & 3000 & 3014 & 3046 & 3080 & 3080 & 3022 & 3059 & 3100 & 3100 & 3120 & 3148 & 3180 & 3180 \\
\hline $\mathrm{NE}$, kcal/kg (prediction) & 2148 & 2210 & 2210 & 2249 & 2282 & 2290 & 2290 & 2320 & 2346 & 2300 & 2300 & 2338 & 2368 & 2379 & 2380 & 2414 & 2433 \\
\hline SID Lysin & 1.05 & 0.96 & 0.96 & 0.96 & 0.96 & 0.96 & 0.96 & 0.96 & 0.96 & 0.90 & 0.90 & 0.90 & 0.90 & 0.90 & 0.90 & 0.90 & 0.90 \\
\hline SID Met + Cys & 0.71 & 0.75 & 0.75 & 0.75 & 0.75 & 0.75 & 0.75 & 0.75 & 0.75 & 0.67 & 0.67 & 0.67 & 0.67 & 0.67 & 0.67 & 0.67 & 0.67 \\
\hline SID Threonin & 0.65 & 0.62 & 0.62 & 0.62 & 0.62 & 0.62 & 0.62 & 0.62 & 0.62 & 0.59 & 0.59 & 0.59 & 0.59 & 0.59 & 0.59 & 0.59 & 0.59 \\
\hline SID Arginin & & 0.86 & 0.81 & 0.83 & 0.87 & 0.87 & 0.83 & 0.82 & 0.91 & 0.9 & 0.86 & 0.85 & 0.87 & 0.86 & 0.85 & 0.85 & 0.85 \\
\hline SID Tryptophan & 0.18 & 0.15 & 0.12 & 0.13 & 0.16 & 0.15 & 0.13 & 0.13 & 0.16 & 0.15 & 0.13 & 0.12 & 0.15 & 0.15 & 0.13 & 0.12 & 0.15 \\
\hline
\end{tabular}

a Premix compound provided per kg of diet: retinol, $3.0 \mathrm{mg}$; cholecalciferol, $0.045 \mathrm{mg}$; tocopherol, 20mg; menadione, $3.5 \mathrm{mg}$; riboflavin, $8.0 \mathrm{mg}$; niacin, $35 \mathrm{mg}$; D-pantothenic acid, 10 mg; cobalamin, 0.015 mg; biotin, 0.18mg; folacin, 1.2mg; thiamine, 2.0 mg; pyridoxine, 3.5 mg; 8.0 mg of Cu from CuSO4.5H20; 80 mg of Zn from ZnSO4. H2O; 100 mg of Mn from $\mathrm{MnSO} 4 \cdot \mathrm{H} 2 \mathrm{O} ; 60 \mathrm{mg}$ of Fe from FeSO4.H2O; $0.7 \mathrm{mg}$ of I from Kl; $0.3 \mathrm{mg}$ of Se from Na2SeO3. 
the starter phase. Diets 1 through 8 were formulated to provide 2920 (2210), 2955 (2210), 3000 (2249), 3000 (2282), 3014 (2290), 3046 (2290), 3080 (2320), 3080 (2346) kcal AME (or NE)/kg, respectively, in the grower phase. Diets 1 through 8 were formulated to provide 3022 (2300), 3059 (2300), 3100 (2338), 3100 (2368), 3120 (2380), 3148 (2280), 3180 (2414), 3180 (2433) kcal AME (NE)/kg, respectively, in the finisher phase. The AME values of feed ingredients, crude protein and crude fat levels are shown in Table 2. The NE values of feed ingredients were calculated using the predictive equation reported by Wu et al. (2019). The room temperature was maintained at $32-34^{\circ} \mathrm{C}$ for the first 3 days, and then reduced by $2-3^{\circ} \mathrm{C}$ per week to a final temperature of $20^{\circ} \mathrm{C}$. The chickens had ad libitum access to feed and water throughout the experimental period. At 21, 42, and 58 days of age, the weights of the chickens were measured after 12-h feed deprivation, and feed consumption was recorded to calculate the average daily feed intake (ADFI), the average daily gain (ADG), and the feed: gain ratio (F/G).

Table 2 - Main measured characteristics of the diets used in the NE prediction equation.

\begin{tabular}{|c|c|c|c|c|}
\hline \multirow[t]{2}{*}{ Items } & \multicolumn{2}{|c|}{$\begin{array}{c}\text { Composition, \% DM } \\
\text { basis }\end{array}$} & \multicolumn{2}{|c|}{$\begin{array}{c}\text { Energy values, Kcal/ } \\
\text { kg DM }\end{array}$} \\
\hline & $C P^{a}$ & $\mathrm{EE}^{\mathrm{a}}$ & $\mathrm{AME}^{\mathrm{b}}$ & $\mathrm{NE}^{\mathrm{c}}$ \\
\hline Corn & 9.07 & 4.07 & 3686 & 2846 \\
\hline Soybean meal & 53.51 & 2.03 & 2791 & 1836 \\
\hline Cottonseed meal & 52.82 & 2.18 & 2437 & 1565 \\
\hline Corn gluten meal & 67.43 & 0.94 & 3928 & 2623 \\
\hline Wheat & 13.64 & 3.98 & 3750 & 2865 \\
\hline Soybean oil & & 100.00 & 9091 & 7793 \\
\hline Rapeseed meal & 42.67 & 3.47 & 2469 & 1667 \\
\hline Pea & 21.28 & 1.77 & 3058 & 2258 \\
\hline Barely & 10.09 & 2.47 & 2976 & 2273 \\
\hline Extruded soybean & 38.97 & 21.20 & 3981 & 2996 \\
\hline Palm Ouricuri Meal & 16.13 & 10.42 & 1954 & 1490 \\
\hline Lysine- $\mathrm{H}_{2} \mathrm{SO}_{4}(70 \%)$ & 78.57 & & 2296 & 1267 \\
\hline DL-Methionine (98\%) & 58.99 & & 4684 & 3263 \\
\hline Threonine (98\%) & 73.88 & & 3077 & 1908 \\
\hline
\end{tabular}

${ }^{a} \mathrm{CP}$ and $\mathrm{EE}$ were measured value.

${ }^{\mathrm{b}}$ AME data from poultry feed database of Wens Foodstuff Group.

' NE predicted using regression equations: NE (MJ/kg DM basis) $=0.781 \times \mathrm{AME}(\mathrm{MJ} /$ $\mathrm{kg} \mathrm{DM}$ basis $)-0.028 \times \mathrm{CP}(\% \mathrm{DM}$ basis $)+0.029 \times \mathrm{EE}(\% \mathrm{DM}$ basis $)$ produced from Wu et al (2019).

\section{Statistical analyses}

The data were analyzed by one-way analysis of variance (ANOVA) using SAS version 9.4 (SAS Inst. Inc., Cary, NC). The performance of each pen was used as the experimental unit. All data were tested for normality and homoscedasticity before analysis using the Shapiro-Wilk and Levene tests, respectively.
Significant differences among treatments were determined by Duncan's multiple range test (Duncan, 1955). Significance was set at $p<0.05$ and values are presented as means \pm standard error of the mean (SEM). The linear regression model is expressed as $Y$ $=\beta 0+\beta 1 \times \mathrm{X}, R^{2}$, where $\mathrm{Y}$ is the energy level, $\mathrm{X}$ is the response variable (ADG, $A D F I$, or $F / G$ ), and $\beta 0$ and $\beta 1$ are regression parameters.

\section{RESULTS AND DISCUSSION}

The more accurate the energy system, the better the prediction of production performance. In pigs, $\mathrm{NE}$, which is a measure of 'true' energy available for maintenance and production, predicted the production performance more accurately than the digestible energy (DE) or ME did. In chickens, the efficiency of AME and NE for prediction of production were less dependent on dietary nutrient contents than they were in pigs, suggesting that the NE system might not be more suitable than the AME system. Our study assessed whether the NE system was advantageous to determine the efficiency of feed utilization in Chinese Yellow Chickens. In the starter phase of the experiment, a large number of unconventional raw materials were used and formulations differed among treatments. To avoid the effects of these factors on the analysis, the starter phase was excluded from the experiment.

Dietary energy affects broiler growth performance in terms of ADG and ADFI. Live weight gain is higher, feed intake is lower, and food conversion efficiency improves with the increase in dietary energy levels. In the present study, an increase in AME content from 2975 to $3117 \mathrm{kcal} / \mathrm{kg}$ was associated with an increase by ADG to $2.85 \%$. Accordingly, the ADFI and FCR of the chickens decreased by $0.69 \%$ and $3.51 \%$, respectively (Table 3 ). The correlations between energy value and production performance indicators suggested significant differences among ADG, ADFI and FCR, favoring the use of NE. In contrast to ADG and $A D F I, F C R$ significantly changed with dietary energy values. However, there were no significant differences in production performance between the different treatments with graded levels of dietary energy $(p>0.05)$, because the chickens were fed at the same growth stage. In the later stages of the diet, FCR values decreased as ME of the diet increased, and the differences became highly significant $(p<0.01)$. In addition, a strong linear correlation between $\mathrm{ME}$ values in the diets and FCRs in chickens was found, with correlation coefficients of $0.373,0.9287$ and 


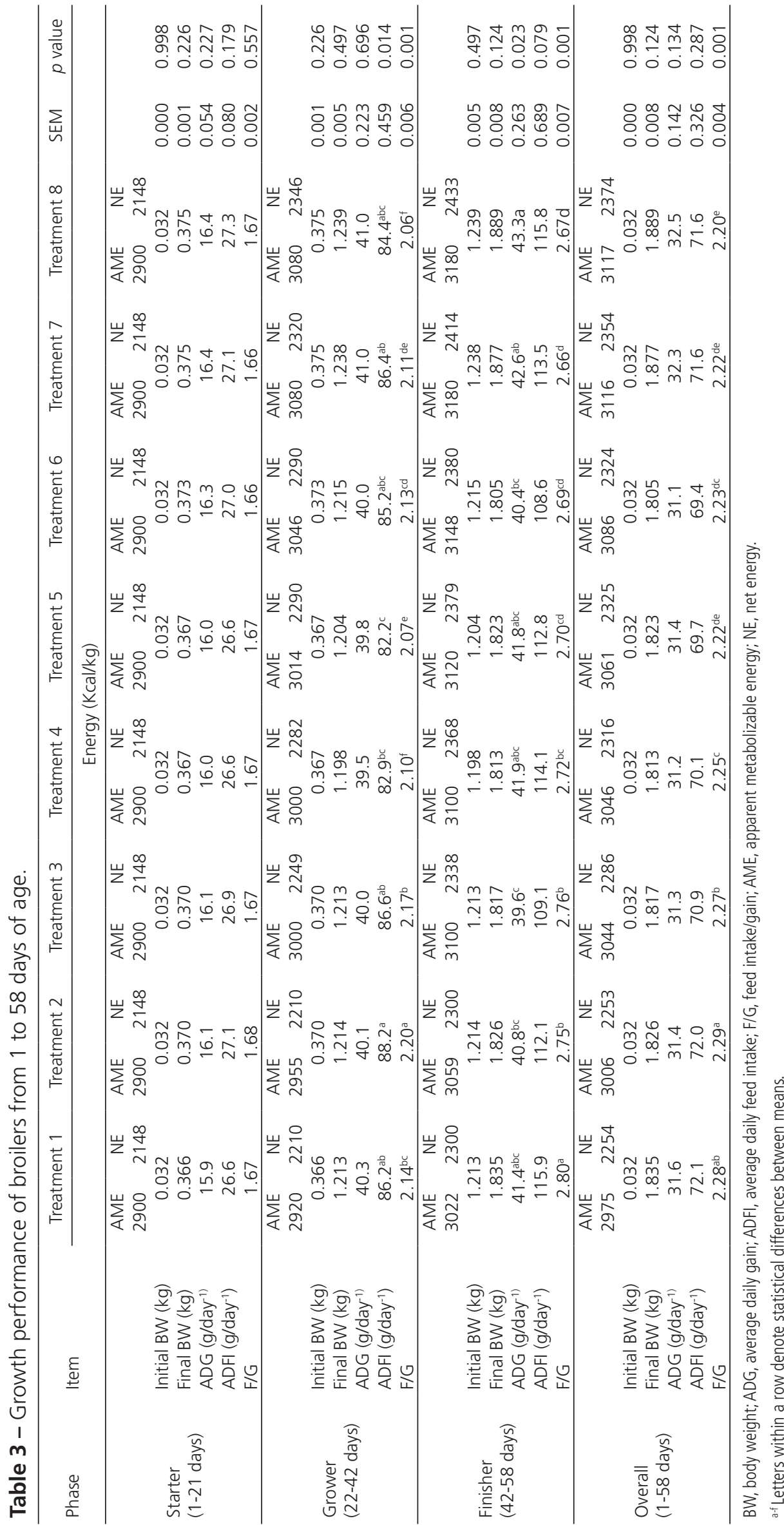

0.8272 , respectively, in the grower, finisher and overall stages (Table 4). There were non-significant linear correlations between the ADFI and AME values, and ADG ( $p>0.05)$. Therefore, compared with ADFI and $A D G, F C R$ is a sensitive measure for evaluation of the effects of energy value on production performance, because chickens fed a balanced diet responded to the energy level of the diet. Thus, when the energy level is accurately known, the relationship between $F C R$, as a major indicator of performance, and dietary energy level improves.

Indeed, in the current study, energy levels and FCR were highly correlated. The regression analyses of FCRs and diets prepared in accordance with the ME and NE databases for chickens are shown in Table 4. There was a significant linear correlation between FCR and the ME value of the feed prepared in accordance with our own ME database specifically for the Chinese Yellow Chicken $(p<0.01)$. The linear regression equation between the ME value and FCR was $A M E=-1435.5 \times F / G+6278.2$, where $R^{2}=0.8272$. The correlation became much stronger when the feed was formulated using our NE database $(p<0.01)$. The linear regression equation between the NE value and $F C R$ was $N E=-1350.1 \times F / G+5340.9$, where $R^{2}=0.9551$. This clearly indicates that the diets prepared using the NE database were more accurate for evaluating production performance in chickens than those based on an ME database. However, there were differences in the correlations between FCRs and diets prepared in accordance with $\mathrm{NE}$ and ME systems at different stages. At the grower stage, the linear regression equation between $\mathrm{ME}$ and FCR was $\mathrm{AME}=-733.9 \times \mathrm{F} /$ $\mathrm{G}+4569.4$, where $R^{2}=0.3743$. The 
Table 4 - The relationship between growth performance and diet energy.

\begin{tabular}{|c|c|c|c|c|}
\hline Energy system & & Item & Regression Equations & $\mathrm{R}^{2 \mathrm{a}}$ \\
\hline \multirow{9}{*}{ AME } & \multirow{3}{*}{$\begin{array}{l}\text { Grower } \\
\text { (22-42 days) }\end{array}$} & ADG (g/day ${ }^{-1)}$ & $A M E=55.953 \times A D G+762.98$ & 0.2716 \\
\hline & & ADFI $\left(g /\right.$ day $\left.^{-1}\right)$ & $A M E=-8.3973 \times A D F I+3727.9$ & 0.0881 \\
\hline & & $F / G$ & AME $=-733.9 \times F / G+4569.4$ & 0.3743 \\
\hline & \multirow{3}{*}{$\begin{array}{l}\text { Finisher } \\
\text { (42-58 days) }\end{array}$} & ADG (g/day ${ }^{-1)}$ & $A M E=22.614 \times A D G+2175.7$ & 0.2363 \\
\hline & & ADFI $\left(g /\right.$ day $\left.^{-1}\right)$ & $A M E=-2.1659 \times A D F I+3357.8$ & 0.0115 \\
\hline & & $F / G$ & AME $=-1127.2 \times F / G+6178.1$ & 0.9287 \\
\hline & \multirow{3}{*}{$\begin{array}{l}\text { Overall } \\
\text { (22-58 days) }\end{array}$} & ADG (g/day $\left.{ }^{-1}\right)$ & $\mathrm{AME}=49.782 \times \mathrm{ADG}+1483.2$ & 0.2761 \\
\hline & & ADFI $\left(g /\right.$ day $\left.^{-1}\right)$ & $A M E=-13.082 \times A D F I+3984.2$ & 0.0781 \\
\hline & & $F / G$ & AME $=-1435.5 \times F / G+6278.2$ & 0.8272 \\
\hline \multirow{9}{*}{ NE } & \multirow{3}{*}{$\begin{array}{l}\text { Grower } \\
\text { (22-42 days) }\end{array}$} & ADG (g/day ${ }^{-1)}$ & $\mathrm{NE}=42.624 \times \mathrm{ADG}+561.46$ & 0.2116 \\
\hline & & $\operatorname{ADFI}\left(\mathrm{g} /\right.$ day $\left.^{-1}\right)$ & $\mathrm{NE}=-12.914 \times \mathrm{ADFI}+3727.9$ & 0.0881 \\
\hline & & $F / G$ & $\mathrm{NE}=-851.07 \times \mathrm{F} / \mathrm{G}+4080.8$ & 0.6758 \\
\hline & \multirow{3}{*}{$\begin{array}{l}\text { Finisher } \\
\text { (42-58 days) }\end{array}$} & ADG (g/day ${ }^{-1)}$ & $N E=26.974 \times A D G+1245.2$ & 0.4405 \\
\hline & & $\operatorname{ADFI}\left(\mathrm{g} /\right.$ day $\left.^{-1}\right)$ & $\mathrm{NE}=2.2725 \times \mathrm{ADFI}+2107.8$ & 0.0166 \\
\hline & & $F / G$ & $N E=-954.72 \times F / G+4959.5$ & 0.8729 \\
\hline & \multirow{3}{*}{$\begin{array}{l}\text { Overall } \\
\text { (22-58 days) }\end{array}$} & ADG (g/day ${ }^{-1)}$ & $\mathrm{NE}=47.991 \times \mathrm{ADG}+794.17$ & 0.3349 \\
\hline & & ADFI $\left(g /\right.$ day $\left.^{-1}\right)$ & $\mathrm{NE}=-11.578 \times \mathrm{F} / \mathrm{G}+3131.9$ & 0.0799 \\
\hline & & $F / G$ & $N E=-1350.1 \times F / G+5340.9$ & 0.9551 \\
\hline
\end{tabular}

${ }^{a}$ Coefficient of determination $\left(R^{2}\right)$ was obtained using data from all treatments.

linear regression equation between NE value and FCR was $\mathrm{NE}=-851.07 \times \mathrm{F} / \mathrm{G}+4080.8$, where $R^{2}=0.6758$. At different stages of production, there were differences between the two databases. At the grower stage, the improved accuracy of the NE over the ME database was very apparent. However, at the finisher stage, the linear regression equation between ME value and FCR was $\mathrm{AME}=-1127.2 \times \mathrm{F} / \mathrm{G}+6178.1$, where $R^{2}=0.9287$. The linear regression equation between NE and FCR was $\mathrm{NE}=-954.72 \times \mathrm{F} / \mathrm{G}+4959.5$, where $R^{2}=0.8729$. Compared with ME, NE showed a significant difference in the production performances of chickens at the finisher stage. The reasons for the non-significant differences might be related to the sources of ME data for the feed ingredients used at the fattening stage (128 d) in this study; the NE equation generated by Wu et al. (2019) was obtained using broiler chickens, at the grower phase ( $25 \mathrm{~d}$ ). Although Chinese Yellow Chickens are long-lived birds with a slaughter age reaching over $100 \mathrm{~d}$. The final stage of growth is slow and the diet is very different to that of the modern broiler. Wu et al might need to look at NE values at different stages of growth to make corrections to their equations.

\section{CONCLUSION}

The NE system developed by Wu et al. (2019) was evaluated in the Chinese Yellow Chicken to examine wether it could predicted bird performance better than the current AME system. The NE is more accurate in predicting FCR than the AME system, especially during the grower phase of the Chinese Yellow Chicken. However, the differences in the NE system and ME systems blurred during the fattening stage of chickens, suggesting that further optimization of the NE system is required to tailor the energy needs of the Chinese Yellow Chicken for the later stages of its production.

\section{CONFLICT OF INTERESTS}

The authors declare that there is no conflict of interest regarding the publication of this paper.

\section{ACKNOWLEDGEMENTS}

This work was supported by the project of Innovation Team in Modern Agricultural Industry Technology System from Guangdong Province (2018LM1059).

\section{REFERENCES}

Carré $B$, Lessire $M$, Juin $\mathrm{H}$. Prediction of the net energy value of broiler diets. Animal 2014;8:1395-1401.

De Groote G. A comparison of a new net energy system with the metabolisable energy system in broiler diet formulation, performance and profitability. British Poultry Science 1974;15:75-95.

Gous R. An effective alternative to the metabolisable energy system Proceedings of the 21st Annual Australian Poultry Science Sumposium, 2010 Feb 1-3rd; Sydney, New South Wales; 2010. p.36-43.

Leeson S, Caston L, Summers J. Broiler response to diet energy. Poultry Science 1996;75:529-535.

Noblet J. Energy evaluation of pig feeds with emphasis on net energy. Proceedings of the 12th BOKU Symposium Tierernäahrung; 1994; Vienna. p.13-18. 
Noblet J, Dubois S, Lasnier J, Warpechowski M, Dimon P, Carré B, et al. Fasting heat production and metabolic BW in group-housed broilers. Animal 2015;9:1138-1144.

NRC - National Research Council. Nutrient requirements of swine. $11^{\text {th }}$ ed. Washington: National Academic Press; 2012.

Ren L, Tan H, Zhao F, Zhao J, Zhang J, Zhang H. Using corn starch as basal diet to determine the true metabolizable energy of protein feedstuffs in chinese yellow chickens. Poultry Science 2012;91:1394-1399.

Sakomura NK, Modeling energy utilization in broiler breeders, laying hens and broilers. Brazilian Journal of Poultry Science 2004;6:1-11.

Sibbald IR, Morse PM. Effects of the nitrogen correction and of feed intake on true metabolizable energy values. Poultry Science 1983;62:138142.
Swick RA, Wu S, Rodgers N, Choct M. Poultry C: energy systems for broilers-recent developments and relevance for feed formulation. Proceedings of the $5^{\text {th }}$ International Broiler Nutritionists' Conference; 2014. New Zealand: Poultry Industry Association of New Zealand; 2014

Van der Klis J, Jansman A. Net energy in poultry: its merits and limits. The Journal of Applied Poultry Research 2019;28:499-505.

Waldroup P. Energy levels for broilers. Journal of the American Oil Chemists' Society 1981;58:309-313.

Wu S-B, Swick RA, Noblet J, Rodgers N, Cadogan D, Choct M. Net energy prediction and energy efficiency of feed for broiler chickens. Poultry Science 2019;98:1222-1234 